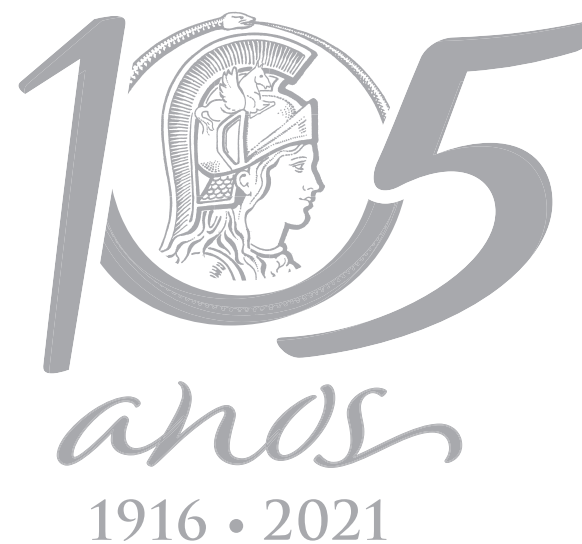

$1916 \cdot 2021$

SOIL SCIENCE

\title{
Biological activity of bacteria isolated from wetland sediments collected from a conservation unit in the southern region of Brazil
}

\author{
PRISCILA R. JANKOSKI, ANA PAULA F. CORREA, ADRIANO BRANDELLI \& AMANDA \\ S. DA MOTTA
}

\begin{abstract}
Wetlands are ecosystems rich in biodiversity and their ecological importance is recognized worldwide. Sediment samples were subjected to physical-chemical analysis and organic carbon content varied from $3.0 \%$ to $4.8 \%$, the clay between 32 and $40 \%$, silt with $41 \%$ and $43 \%$, sand coarse varied between 6 and $11 \%$ and fine sand between 7 and $16 \%$. The nitrogen values varied from $0.25 \%$ to $0.48 \%$, the $\mathrm{pH}$ from 5.4 to 7.5 and the humidity varied from 44 to $56 \%$. The selected isolates were evaluated for enzymatic properties and $64 \%$ showed positive results for amylase, $16 \%$ for gelatinase, $37 \%$ for lipase, $91 \%$ for protease and $2.7 \%$ for inulinase. Six bacterial isolates were selected for the overlapping assay and Bacillus sp. sed 2.2 showed inhibitory activity against Corynebacterium fimi NCTC 7547, and the antimicrobial substance was partially purified. The characterization of the substance was carried and the substance was stable at $100^{\circ} \mathrm{C}$ for up to 10 minutes and sensitive to the enzymes papain and trypsin. This substance was active against some species of Listeria, including Listeria monocytogenes ATCC 7644. The microorganims obtained from sediment samples were important sources of bioactive compounds, including enzymes and peptides, being a source of bioactive compounds to be studied.
\end{abstract}

Key words: Antimicrobial, Bacillus, bioactive properties, peptide purification, wetlands.

\section{INTRODUCTION}

Wetlands are important ecosystems with high dynamism found in virtually all regions of the world (Jungblut et al. 2012). The microorganisms present there play important ecological roles and are fundamental for the adequate functioning of these environments ( $\mathrm{Hu}$ et al. 2014). In order to characterize the composition of the bacterial community in the soil of a humid area, the technique of equations of the $16 \mathrm{~S}$ rRNA gene was used by Ansola et al. (2014) and the main microbial groups found were: Proteobacteria, Verrucomicrobia and Chloroflexi. Panosyan et al. (2018) analyzed the composition of the bacterial community of a soil and most of the bacterial genera found were Halobacillus (41.2\%), Piscibacillus (23.5\%), Bacillus (23.5\%) and Virgibacillus (11.8\%).

The importance of studying these environments goes far beyond just identifying the microbial community, since many of these microorganisms are producers of compounds involved in different active biological processes. Li et al. (2017) investigated the diversity of extracellular protease-producing bacteria in China and, of the 121 isolates studied, identified bacteria belonging to the Pseudoalteromonas (40.5\%), Bacillus (36.3\%), and Photobacterium (5.8\%) genera. Ghani et al. (2013) isolated different strains of Bacillus licheniformis for 
the production of commercially important extracellular enzymes, and observed a potential for alpha-amylase, protease, pectinase and cellulase production. In addition, the microorganisms that inhabit soil produce many biologically active, natural products, including important antibiotics (Kumar et al. 2014). Some species of the genus Bacillus are producers of secondary metabolites, including antifungals, plant growth promoters, siderophores and bacteriocins (Mora et al. 2015, Leite et al. 2016 ,Sansinenea et al. 2016). In their research, Salazar et al. (2017) characterized two cofactors with antifungal and antibacterial potential produced by Bacillus amyloliquefaciens ELI 149, which brought to light the broad spectrum of these compounds. Mora et al. (2015) isolated several species of Bacillus that demonstrated antimicrobial activity, showing excellent potential against tested phytopathogens. These studies are examples of research performed with the objective of characterizing new compounds exhibiting antimicrobial activity. This is because they off new alternatives for researching molecules that present multiple possibilities for biological control, either for the environment, biopreservation of food biopharmaceuticals (Duarte et al. 2013, Shashidar et al. 2017).

Thus, the present study aims to study bacterial isolates from wetland sediments, from four distinct points of the Imperatriz Leopoldina Conservation Unit and to examine for hydrolytic enzyme production and antimicrobial compounds, as there is currently no information in the literature on the bioactive potential of bacteria from the Imperatriz Leopoldina Conservation Unit in São Leopoldo, Brazil.

\section{MATERIALS AND METHODS}

\section{Area of study and collection of sediment samples}

The sediment samples were collected in a wet area of the Imperatriz Leopoldina Municipal Natural Park, located in the municipality of São Leopoldo, Southern Brazil, in the months of January, April and May 2017. The area was divided into four quadrants from which four sediment samples were collected. Five hundred grams were collected for physicochemical analysis and $100 \mathrm{~g}$ for the counting of heterotrophic bacteria sampled at a depth of $40 \mathrm{~cm}$ from the surface, with the aid of dredge-type equipment. Samples were transferred to sterile vials and transported under refrigeration to the Laboratory of Microbiology at the Instituto de Ciências Básicas da Saúde, Federal University of Rio Grande do Sul (Porto Alegre, Brazil).

\section{Physico-chemical analysis of sediment samples}

Three sediment samples were submitted to physicochemical analysis (Point 1, 2 and 3). These points were chosen because they have different characteristics in the sampled environment. To determine organic carbon, the technique used was the Wet Combustion; grain size determination was evaluated by dispersion; the Kjeldahl method allowed nitrogen detection; $\mathrm{pH}$ was measured by potentiometry and humidity was determined by gravimetry, according to Tedesco et al. (1995). The analyzes were performed by the Soil Laboratory of the School of Agronomy of the Federal University of Rio Grande do Sul - UFRGS / RS.

\section{Heterotrophic bacteria count from sediment samples}

Twenty-five gram pellets from each sample were weighed and then transferred to Erlenmeyer 
flasks containing $225 \mathrm{ml}$ of $0.85 \%$ saline dilution corresponding to $10^{-1}$. From this dilution, decimal dilutions were made in triplicate to the $10^{-8}$ dilution. Next, samples were inoculated on to standard agar for counting, using the surface scattering technique, and plates were incubated at $37^{\circ} \mathrm{C}$ for $24-48 \mathrm{~h}$. For counting, plates with a number of between 25 and 250 colonies were used and the results were expressed as colony forming units/gram of sediment (cfu/g). After the counting of heterotrophic bacteria, bacterial colonies presenting different morphologies were selected, seeded on to tryptone soya agar and incubated once more at $37^{\circ} \mathrm{C}$ for $24 \mathrm{~h}$. This was done to evaluate the purity of the isolates, as well as the subsequent identification of morpho tinctorial properties.

\section{Identification of bacterial isolates by Matrix Associated Laser Desorption-Ionization-Time of Flight (MALDI-TOF/MS)}

After being cultivated in tryptone soya agar, for 24 hours, a colony of each isolate was inoculated in microtubes with $300 \mu \mathrm{l}$ of ultrapure water and $900 \mu \mathrm{l}$ of ethanol. Subsequently, samples were centrifuged at 13,000 rpm for $2 \mathrm{~min}$. After, the supernatant was discarded and the pellet was dried at room temperature. Then, 70\% formic acid $(30 \mu \mathrm{l})$ and acetonitrile $(30 \mu \mathrm{l})$ were added to the sediment, followed by homogenization in vortex and a new centrifugation step forming of a pellet. Immediately after, approximately $1 \mu \mathrm{l}$ supernatant was pipetted onto a stainless steel plate and allowed to dry at room temperature. Subsequently, $1 \mu \mathrm{l}$ of matrix, consisting of a-cyano-4-hydroxycinnamic acid solution (HCCA) was added (Sauget et al. 2017). The analyses were performed in a MALDI Biotyper 4.0 device with MBT OC software, at the Instituto de Ciências Básicas da Saúde at the Federal University of Rio Grande do Sul.

\section{Evaluation of the production of hydrolytic enzymes by selected bacteria}

For the amylase test the bacterial isolates were seeded onto plates containing nutrient agar, supplemented with a $0.2 \%$ soluble starch solution. The cultures were incubated at $37^{\circ} \mathrm{C}$ for $48 \mathrm{~h}$ and the Bacillus subtilis ATCC 19659 strain was used as a positive control (Hankin \& Anagnostakis 1975). To evaluate proteolytic activity, bacterial isolates were seeded onto plates containing $10 \%$ skim milk agar and incubated under the same conditions. Pseudomonas aeruginosa ATCC 27853 was used as a positive control (Frazier \& Rupp 1928, Montanhini \& Bersot 2013). To verify gelatinase production, bacterial isolates were seeded in tubes containing nutrient broth plus $12 \%$ gelatin and incubated under the conditions described above. The Staphylococcus aureus ATCC25923 was used as a positive control (Marra et al. 2007). For the evaluation of lipolytic activity, isolates were seeded onto plates containing tributyr in agar and incubated at $37^{\circ} \mathrm{C}$ for $72 \mathrm{~h}$. As a positive control, the Candida parapsilosis strain was inoculated (Montanhini \& Bersot 2013). For the evaluation of the inulinase enzymatic activity, isolates were seeded in plates containing inulin agar and incubated at $37^{\circ} \mathrm{C}$ for $48 \mathrm{~h}$ (Ramapriya et al. 2018).

\section{Evaluation of antimicrobial activity by selected bacteria}

The overlay assay was performed and the isolates were inoculated in triplicate by swabbing onto agar plates containing MuellerHinton agar and incubated at $37^{\circ} \mathrm{C}$ for $24 \mathrm{~h}$. After this incubation period, a semi-solid overlay of tryptone soya agar (0.6\%) was poured over them and then inoculated with $1 \%$ of the suspension of Corynebacterium fimi NCTC 7547 or Listeria monocytogenes ATCC 7644 as indicator strains, containing approximately $1.9 \times 10^{8} \mathrm{CFU} / \mathrm{ml}$. The 
inoculated plates were incubated at $37^{\circ} \mathrm{C}$ for $24 \mathrm{~h}$ and after examined for the presence or absence of inhibition zones, which were measured and expressed in millimeters $(\mathrm{mm})$ (Kékessy \& Piguet 1970).

\section{S rRNA gene analysis}

For each selected isolate, a DNA extraction was performed, in addition to amplification and base sequencing by polymerase chain reaction (PCR) in a ThermalCycler model 2720 (Applied Biosystems by Life Technologies ${ }^{\circledR}$ ). The primer for the $16 \mathrm{~S}$ bacterial sequencing was $F$ C27 (AGAGTTTGATCCTGGCTCAG) and $R$ 530 (CCGCGGCTGCTGGCACGTA) (Gontang et al. 2007). The PCR reaction was performed in a total volume of $25 \mu \mathrm{l}$, containing $100 \mathrm{ng}$ of DNA, $1 \mathrm{x}$ reaction buffer of Taq $\left(4 \mathrm{G}^{\circledR}\right), 0.4 \mu \mathrm{M}$ of each primer oligonucleotide (Invitrogen ${ }^{\circledR}$ ), $1.5 \mathrm{mM} \mathrm{MgCl}_{2}\left(4 \mathrm{G}^{\circledR}\right), 200 \mu \mathrm{M}$ dNTPs (Ludwig Biotechnology $\left.{ }^{\circledR}\right), 1 \mathrm{U}$ of Taq DNA polymerase $\left(4 \mathrm{G}^{\circledR}\right)$ and sterile water to complete the reaction volume. PCR was performed under the following conditions: $5 \mathrm{~min}$ at $94^{\circ} \mathrm{C}$, followed by 35 cycles of $1 \mathrm{~min}$ at $94^{\circ} \mathrm{C}, 1.5 \mathrm{~min}$ at $53^{\circ} \mathrm{C}$ and $1.5 \mathrm{~min}$ at $72^{\circ} \mathrm{C}$ with a final extension of $4 \mathrm{~min}$ at $72^{\circ} \mathrm{C}$. The sequencing of the samples was carried out at the ACT Gene Análises Moleculares Ltda. company (Porto Alegre, Brazil) using the AB 3500 Genetic Analyzer automatic sequencer (Applied Biosystems). Sequencing data were collected using the Data Collection 2 program (Applied Biosystems). Results were analyzed using the software Chrome version 2.6.4 (Technelysium Pty Ltd) and compared to the database of the National Center for Biotechnology Information (NCBI) (https://www.ncbi.nlm.nih.gov/).

\section{Production of antimicrobial substances selected by selected isolate}

For antibacterial substance production, the Bacillus sp. sed 2.2 strain was cultivated in a
$100 \mathrm{ml} \mathrm{TSB}$ medium at $30^{\circ} \mathrm{C}$ in a rotary shaker at 50 cycles $/ \mathrm{min}$, for specific times. Viable cell counts (CFU/ml) were determined as described elsewhere (Motta \& Brandelli 2002). After cultivation for $24 \mathrm{~h}$, the cells were harvested by centrifugation at $10,000 \mathrm{~g}$ for $15 \mathrm{~min}$ at 4 으 and the culture supernatant was subjected to precipitation with ammonium sulfate at $60 \%$ $(\mathrm{w} / \mathrm{v})$ saturation. The precipitate was dissolved in $10 \mathrm{mM}$ phosphate at $\mathrm{pH}$ 6.0. This solution was further purified by gel filtration chromatography in a Sephadex G-100 column. Fractions of 1.0 $\mathrm{ml}$ were collected and their absorbance was determined in a spectrophotometer at $280 \mathrm{~nm}$. The fractions were then lyophilized. They were resuspended in $100 \mu \mathrm{l}$ sodium phosphate buffer at pH $6.010 \mathrm{mM}$. After, the antimicrobial activity of the collected fractions was determined according to Motta \& Brandelli (2002). Plates were incubated at $30^{\circ} \mathrm{C}$ for $24 \mathrm{~h}$. The indicator bacterium used was Corynebacterium fimi NCTC 7547.

\section{Determination of the inhibitory spectrum of the partially purified substance}

Suspensions of each of the indicator microorganisms were prepared in $0.85 \%$ $(\mathrm{w} / \mathrm{v}) \mathrm{NaCl}$ according to the turbidity scale of MacFarland 0.5. Each of the suspensions was spread on plates containing Mueller-Hinton agar, or the Mueller-Hinton glucose medium with methylene blue for the Candida species. Then, $20 \mu \mathrm{l}$ of the crude supernatant, obtained through Sephadex G-100 chromatography, was inoculated and incubated under the optimal growth conditions of each indicator microorganism $\left(30^{\circ} \mathrm{C}\right.$ or $\left.37^{\circ} \mathrm{C}\right)$ for $24 \mathrm{~h}$. After the incubation period, formation of inhibition halos was observed, which were measured and expressed in millimeters. Species of the following genera were used: Bacillus, Candida, Corynebacterium, Enterobacter, Enterococcus, 
Escherichia, Listeria, Pseudomonas, Proteus, Salmonella, Shigella and Staphylococcus.

\section{Characterization of partially purified crude supernatant: Thermal and proteolytic enzymes stability}

The thermal stability of the partially purified cell free supernatant by G-100 was determined by exposing the compound to a temperature of $100^{\circ} \mathrm{C}$ for different times: 3, 5, 10 and 15 minutes and $121^{\circ} \mathrm{C} / 105 \mathrm{kPa}$ for 15 minutes (autoclave), according to Motta et al. (2007) with modifications. The experiment was performed in duplicate and the antimicrobial activity of the samples was tested against the Corynebacterium fimi NCTC 7547 indicator strain. For the stability test against proteolytic enzymes, the free cell supernatant obtained by liquid filtration gel chromatography (Sephadex G- 100) was treated with papain and trypsin enzymes at final concentrations of $2 \mathrm{mg} / \mathrm{ml}$. Four microtubes were prepared for each enzyme tested: Tube 1: Control (Proteolytic Enzyme +10 mM Sodium Phosphate Buffer pH 7), Tube 2: Test (Proteolytic Enzyme + Antimicrobial Substance), Tube 3: Control (Antimicrobial Substance) treated by heat, Tube 4: Control (antimicrobial) - not heat treated. After aliquots were prepared, these microtubes were incubated at $37^{\circ} \mathrm{C}$ for 1 hour, then tubes 1,2 and 3 were heated at $100^{\circ} \mathrm{C}$ for 3 minutes to protease inactivation.
For the experiment, $10 \mathrm{mM}$ sodium phosphate buffer at pH 7 was used. After each treatment, the antimicrobial activity was determined in triplicate using the Corynebacterium fimi NCTC 7547 strain and incubated at $30^{\circ} \mathrm{C}$ for 24 hours.

\section{RESULTS}

\section{Collection points of sediment samples}

The sediment samples were taken from four points at the Imperatriz Leopoldina Conservation Unit. Sampling point 1 was located near the shore of the plains, with some shrub species around it. At the second sampling point, plants and running water were present. At the third sampling point, aquatic plants, standing water and many shrub species were densely distributed. The fourth point was difficult to access and the landscape was characterized by a few aquatic plants and tree trunks.

\section{Physicochemical analysis of sediment samples}

Of the four sediment samples collected, three were subjected to their physical and chemical properties (Point 1, 2 and 3). The data obtained showed that the organic carbon content ranged from $3.0 \%$ to $4.8 \%$, according to Table I and it appears that the highest value was found in point 1 , and the lowest in point 2 . In regarding the sediment granulometry, the clay contents varied between $32 \%$ and $40 \%$, while the silt

Table I. Result of the physicochemical parameters analyzed in the three sediment samples collected.

\begin{tabular}{|c|c|c|c|c|c|c|c|c|}
\hline \multirow{2}{*}{$\begin{array}{l}\text { Collecting } \\
\text { points and } \\
\text { date }\end{array}$} & \multirow{2}{*}{$\begin{array}{l}\text { Organic } \\
\text { carbon }\end{array}$} & \multicolumn{4}{|c|}{ Granulometry } & \multirow[b]{2}{*}{ Nitrogen } & \multirow[b]{2}{*}{$\mathrm{pH}$} & \multirow[b]{2}{*}{ Humidity } \\
\hline & & Clay & $\begin{array}{l}\text { Coarse } \\
\text { sand }\end{array}$ & $\begin{array}{l}\text { Thin } \\
\text { sand }\end{array}$ & Silt & & & \\
\hline $\begin{array}{c}\text { Point } 1 \\
24 / 01 / 2017\end{array}$ & $4.8 \%$ & $37 \%$ & $6 \%$ & $16 \%$ & $41 \%$ & $0.48 \%$ & 6.2 & $56 \%$ \\
\hline $\begin{array}{c}\text { Point } 2 \\
07 / 04 / 2017\end{array}$ & $3.0 \%$ & $32 \%$ & $11 \%$ & $14 \%$ & $43 \%$ & $0.25 \%$ & 7.5 & $44 \%$ \\
\hline $\begin{array}{c}\text { Point } 3 \\
12 / 05 / 2017\end{array}$ & $3.2 \%$ & $40 \%$ & $10 \%$ & $7 \%$ & $43 \%$ & $0.30 \%$ & 5.4 & $50 \%$ \\
\hline
\end{tabular}


content values were very close in the three analyzed points: point 1 with $41 \%$ and point 2 and 3 with $43 \%$. The highest percentages of coarse sand were found in point 2 with $11 \%$ and the lowest in point 1 with $6 \%$, while for fine sand the highest percentages were in point 1 with $16 \%$ and the lowest in point 3 with 7\%. Regarding nitrogen values ranged from $0.25 \%$ to $0.48 \%$, the $\mathrm{pH}$ ranged from acid with 5.4, slightly acid with 6.2 and neutral 7.5. The highest values for humidity were observed at point 1 with $56 \%$ and the lowest at point 2 with $44 \%$.

\section{Counting of heterotrophic bacteria from sediment samples}

The sediment collection counts of heterotrophic bacteria were performed in autumn, in the dry season, at a temperature of around $250 \mathrm{C}$. The results obtained from the cultivation in standard agar for counting purposes showed values between $1.8 \times 10^{4} \mathrm{CFU} / \mathrm{g}$ and $5.8 \times 10^{4}$ $\mathrm{CFU} / \mathrm{g}$ sediment, as is shown in Table II. The heterotrophic bacteria count from all collection points was homogeneous. After the cultivation of colonies in tryptone soya agar medium, different morphotypes were chosen. From the plaques with isolates from collection points 1, 2, 3 and 4 , the selected bacterial colonies were 9, 8,10 and 10 , respectively, rounding off the total of 37 bacterial isolates. Of these isolates, 9 were characterized as Gram-negative bacteria and 28 as Gram-positive bacteria.

\section{Preliminary Identification of bacterial isolates by Matrix Associated Laser Desorption- Ionization- Time of Flight (MALDI-TOF/MS)}

Using the MALDI-TOF/MS, a score between 00001699 means unreliable identification, 17001999 probable genus identification, 2000-2299 reliable genus identification and 2,300-3,000 reliable species identification. In relation to the analysis performed on selected isolated, some identifications were made: of the selected 37 bacterial colonies, we were able to reliably identify 13 isolates at the genus level and achieve the probable identification of 6 bacterial isolates at the genus level, as is shown in Table III. Reliable identification was not possible for any of the isolates at the species level and 18 bacterial isolates were not identified at all by MALDI-TOF.

\section{Production of hydrolytic enzymes by selected bacteria}

Upon evaluating the production of different extracellular enzymes, we observed that, of the 37 isolates tested, 24 (64.8\%) degraded starch. Proteolytic activity was verified for 34 isolates, corresponding to $91.8 \%$. Among the isolated microorganisms, only 6 were able to degrade gelatin, corresponding to $16.21 \%$. Lipase production was observed in 14 isolates (37.8\%), as showed in Figure 1, and the enzymatic activity of inulinase was observed in the isolate Bacillus sp. sed 2.2. Among the 37 bacterial isolates, only 2 (5.4\%) were producers of the 4 tested enzymes.

Table II. Quantification of heterotrophic bacteria in the analyzed sediment, per sample collection point.

\begin{tabular}{|c|c|c|}
\hline Collection point & Geographic coordinates & Viable counts (CFU/g of sediment) \\
\hline 1 & S 2945'374"/ W 51으'992" & $2.1 \times 10^{4}$ \\
\hline 2 & S 294'365" / W 51으'982" & $1.8 \times 10^{4}$ \\
\hline 3 & S 294'22.604" / W 51.07'59.069" & $4.5 \times 10^{4}$ \\
\hline 4 & S 2945'22.344"/ W 51.07'58.920" & $5.8 \times 10^{4}$ \\
\hline
\end{tabular}


Nine (24.3\%) isolates tested positive for at least 3 of the tested enzymes. Six (16.2\%) demonstrated a better enzymatic profile, presenting a higher mean halo in at least two tests. These are: Bacillus megaterium sed 1.5 , isolate sed 2.2, Bacillus megaterium sed 2.8, Bacillus sp. sed 3.5, isolate sed 3.11 and isolate sed 4.3.

\section{Evaluation of antimicrobial activity}

From the results of the enzymatic activity, the six isolates presenting the best enzymatic profile were tested for the production of antimicrobial activity through the overlay method. This test showed the presence of inhibitory activity for only one isolate (sed 2.2), which showed an inhibitory halo of $12 \mathrm{~mm}$ against the indicator culture of C. fimi NCTC 7547. Based on this result, isolate sed 2.2 was selected for the following steps of our research. L. monocytogenes ATCC 7644 was not inhibited by any of the isolates under the experimental conditions employed in this test.

\section{S rRNA gene analysis for selected bacterial isolate}

From results regarding the production of hydrolytic enzymes, isolate sed 2.2 was selected as the best performing bacterium. After sequence

Table III. Bacterial isolates analyzed by MALDI-TOF, using the Biotyper 4.0 database and MBT OC software.

\begin{tabular}{|c|c|c|}
\hline Bacterial isolates analyzed by MALDI-TOF & Score & Result * \\
\hline Bacillus megaterium sed 1.4 & 2.179 & Reliable genus identification \\
\hline Bacillus megaterium sed 1.5 & 2.163 & Reliable genus identification \\
\hline Staphylococcus saprophyticus sed 2.1 & 2.072 & Reliable geuns identification \\
\hline Staphylococcus sp. sed 2.3 & 1.815 & Probable genus identification \\
\hline Bacillus megaterium sed 2.4 & 2.038 & Reliable genus identification \\
\hline Rumellibacillus sp. sed 2.5 & 1.838 & Probable genus identification \\
\hline Micrococcus luteus sed 2.6 & 2.223 & Reliable genus identification \\
\hline Bacillus megaterium sed 2.8 & 2.049 & Reliable genus identification \\
\hline Bacillus sp. sed 3.1 & 1.829 & Probable genus identification \\
\hline Bacillus megaterium sed 3.3 & 2.176 & Reliable genus identification \\
\hline Bacillus megaterium sed 3.4 & 2.066 & Reliable genus identification \\
\hline Bacillus sp. sed 3.5 & 1.840 & Probable genus identification \\
\hline Bacillus megaterium sed 3.6 & 2.161 & Reliable genus identification \\
\hline Bacillus megaterium sed 3.9 & 2.221 & Reliable genus identification \\
\hline Bacillus megaterium sed 4.2 & 2.029 & Reliable genus identification \\
\hline Bacillus sp. sed 4.4 & 1.926 & Probable genus identification \\
\hline Bacillus sp. sed 4.8 & 1.937 & Probable genus identification \\
\hline Paenibacillus sp. sed 4.9 & 2.082 & Reliable genus identification \\
\hline Bacillus megaterium sed 4.10 & 2.117 & Reliable genus identification \\
\hline
\end{tabular}

* Interpretation of score values are as follows: 0.000-1.699: unreliable identification; 1.700-1.999: probable genus identification; 2.000-2.299: reliable genus identification; 2.300-3.000: reliable species identification. 
analysis of the $16 \mathrm{~S}$ rRNA gene, the bacterium was identified at the genus level, presenting a 99\% homology with bacteria of the genus Bacillus and subsequently being identified as Bacillus sp. sed 2.2. Its sequence was deposited under accession number MH666075 in the Standard Nucleotide BLAST (retrieved from http://www. ncbi.nlm.nih.gov).

\section{Production of antimicrobial activity by Bacillus sp. sed 2.2}

Bacillus sp. sed 2.2 was incubated under aerobic conditions for $57 \mathrm{~h}$ at $30^{\circ} \mathrm{C}$. Antimicrobial activity of Bacillus sp. sed 2.2 was initially detected in the exponential growth phase and maximum activity was observed from the beginning to the end of the stationary phase, with a longer range of antimicrobial activity between 33 and $48 \mathrm{~h}$ (Figure 2), at $100 \mathrm{AU} / \mathrm{ml}$. The $\mathrm{pH}$ remained at 7.0 throughout cultivation. The antimicrobial substance obtained at approximately $24 \mathrm{~h}$ of culture was purified by ammonium sulfate precipitation and gel filtration chromatography. Thirty aliquots of $1.0 \mathrm{ml}$ were collected and their absorbance at $280 \mathrm{~nm}$ was monitored, after antimicrobial activity against the indicator strain C. fimi NCTC 7547 was verified. The elution profile of collected fractions and presence of antimicrobial activity is displayed in Figure 3.

\section{Determination of the antimicrobial spectrum}

The fractions collected after partial purification showing antimicrobial activity were pooled and used to determine antimicrobial spectrum against various microorganisms, including Grampositive and Gram-negative bacteria, and yeast. The result of the measurement of inhibition halos is shown in Table IV. Antimicrobial activity against pathogenic Gram positive bacteria was verified, including some species of Listeria. However, it was observed that other microbial species were not inhibited, such as Listeria ivanovii ATCC 19119, Listeria innocua ATCC 33090, L. innocua ATCC 1572, Bacillus subtilis ATCC 19659, Enterococcus faecalis ATCC 29212, E. faecalis ATCC 51299, Staphylococcus aureus ATCC 25923, S. aureus ATCC 29213, S. aureus ATCC 35591, Staphylococcus epidermidis ATCC 35954, L. monocytogenes 4B carcass (food), L. innocua 6B (food), L. monocytogenes 17D78/03 (food), L. monocytogenes 4C (food), L. innocua (buffalo milk), L. innocua L10 (buffalo milk),

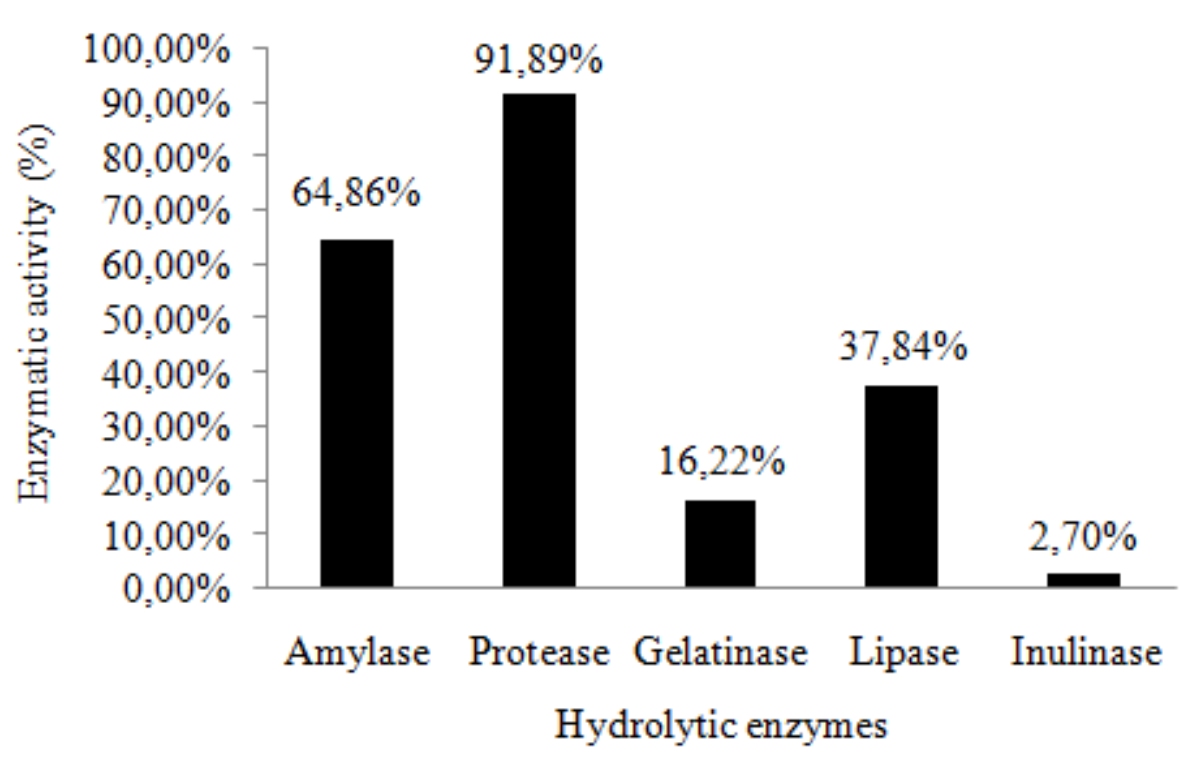

Figure 1. Production of extracellular enzymes by the 37 bacterial isolates found in the sediment samples from Imperatriz Leopoldina Municipal Natural Park, São Leopoldo, Brazil. Values into the bars indicate the number of isolates positive for the respective enzymatic activity. 
L.innocua L11 (buffalo milk), L. innocua L13 (buffalo milk), L. monocytogenes FF Oxford - 6 (sliced cheese), Enterobacter aerogenes ATCC 13048, Shigella dysenteriae ATCC 13313, Proteus mirabilis ATCC 7002, Salmonella Enteritidis ATCC 13076, Escherichia coli ATCC 10536, Pseudomonas aeruginosa ATCC 27853, Candida albicans ATCC 90028, Candida parapsilosis ATCC 22019 and Candida krusei ATCC 6258.

\section{Thermal and proteolytic enzymes stability of partially purified crude supernatant}

The fractions that showed antimicrobial activity after liquid filtration gel chromatography (Sephadex G-100) were pooled (fractions 6, 7, 8, 9 and 10) and tested for thermal stability. The partially purified crude supernatant was stable at $100^{\circ} \mathrm{C}$ for 3,5 and 10 minutes. When the partially purified crude supernatant was subjected to 15 minutes at $100{ }^{\circ} \mathrm{C}$ the activity was completely inactivated. These results were similar when the substance was subjected to a temperature of 121 ㅇ for 15 minutes (autoclave), where the substance was also completely inactivated.
The fractions that showed antimicrobial activity after liquid filtration gel chromatography (Sephadex G-100) were pooled (fractions 6, 7, 8, 9 and 10) and tested against proteolytic enzymes. The studied substance was sensitive to enzymes (papain and trypsin) at the final concentration of $2 \mathrm{mg} / \mathrm{ml}$. These results suggest that the compound is of a protein nature.

\section{DISCUSSION}

Wetlands are ecosystems rich in biodiversity, and their ecological importance is recognized worldwide (Junk 2013, Richardson et al. 2015). Some studies have shown that organic matter, total nitrogen, inorganic nitrogen, chemical oxygen demand (COD), and $\mathrm{pH}$ are determinants of bacterial community composition found in soil (Ansola et al. 2014, Ligi et al. 2014, Arroyo et al. 2015, Ding et al. 2015). In this study, 37 microorganisms were isolated; of these, 19 isolates were identified at genus level via MALDITOF/MS. Mass spectrometry is an important tool as it is an accurate and rapid method for the

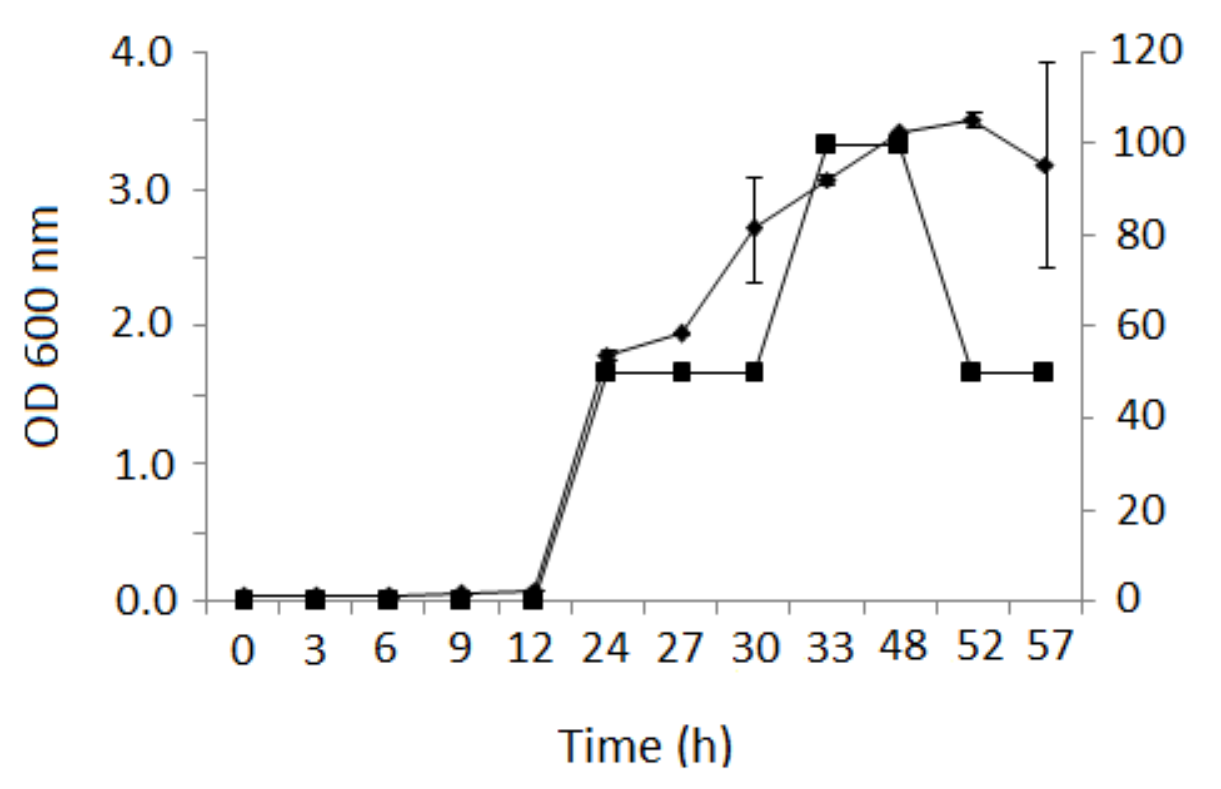

Figure 2. Growth curve and antimicrobial activity of Bacillus sp. sed 2.2. The isolate was cultivated in TSB medium at $300 \mathrm{C}$ and the optical density at $600 \mathrm{~nm}(\diamond)$ and antimicrobial activity ( -) were evaluated for up to 57 h. Each point represents the mean \pm standard deviation of three independent experiments. 
identification of bacterial isolates in clinical field. However, its application in an ecological context, with bacteria of environmental origin, is still limited (Hausdorf et al. 2013). Nevertheless, some researchers have been using this tool to identify environmental bacteria. Of the 45 bacteria isolated from a marine environment, Timperio et al. (2017) identified 16 bacteria at the species level and 23 by genus. Lovecka et al. (2015) isolated 7 bacterial strains from contaminated soil and 3 were classified as safe at the genus level. Kopcakova et al. (2014) sought to identify bacteria isolated from industrial residues and, among 29 bacterial isolates, 27.6\% were successfully identified at genus level and $31 \%$ received probable genus identification. Because of this difficulty, especially with regard to the genus Bacillus, other tools are being used to confirm bacterial identification. Moreover, the genus Bacillus is often isolated from soil samples and contains several groups of species whose close relation makes identification difficult (Starostin et al. 2015). One example are the species Bacillus subtilis, Bacillus amyloliquefaciens and Bacillus pumilus, which have highly similar $16 S$ rRNA gene sequences. This similarity makes it a challenge to distinguish between them based on the above method of analysis. To overcome this disadvantage, other genes such as recA, rpoB, gyrB are being studied as alternative methods for differentiation among Bacillus species (Mohkam et al. 2016).

The bioactive properties of isolated bacteria were studied during the course of our research and these demonstrated the potential to produce compounds with enzymatic and antimicrobial activity. The isolate Bacillus sp. sed 2.2, from collection point 2, was selected as the microorganism with the best performance in the evaluated properties. A study by Correia et al. (2014), which evaluated the enzyme potential of bacteria collected from the sediment of a mangrove swamp, found that approximately $60 \%$ of the isolates displayed amylase activity while $26 \%$ presented lipase activity. These results are similar to those found in our study, in which $64 \%$ of the isolates presented amylolytic activity and 37\% lipolytic activity. Arumugam et al. (2017) described the importance of investigating bacteria from wetlands for the

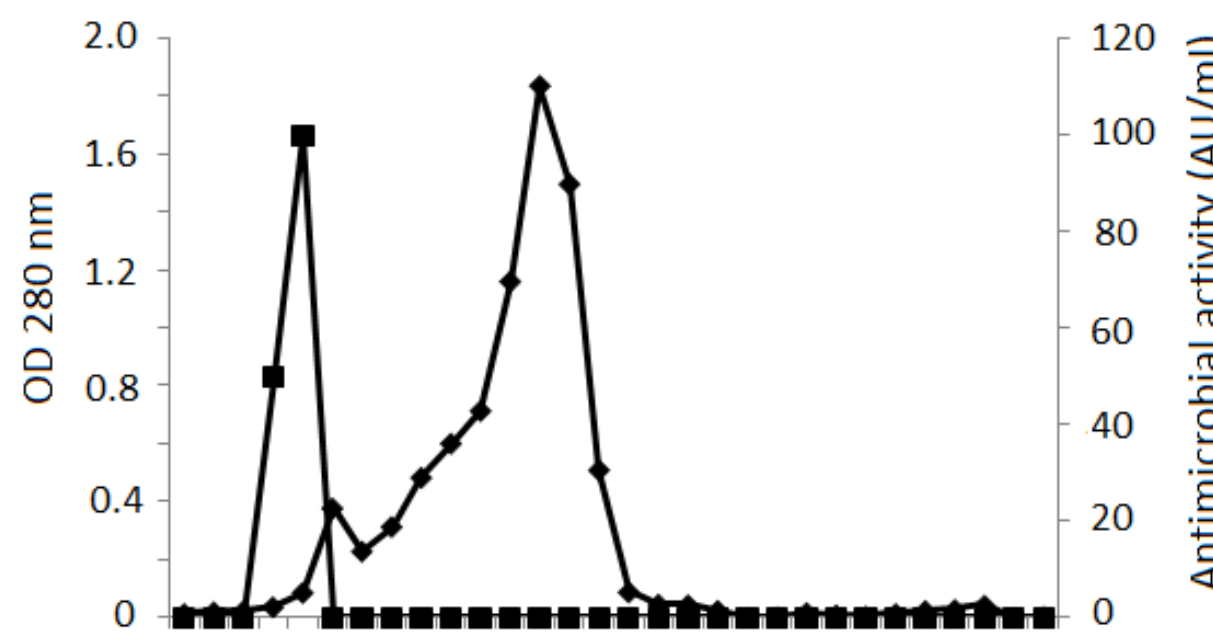

$\begin{array}{lllllllllllllll}1 & 3 & 5 & 7 & 9 & 11 & 13 & 15 & 17 & 19 & 21 & 23 & 25 & 27 & 29\end{array}$

Fraction number 
purpose of being used industrially. The same authors found that the vast majority of bacteria studied produced amylase, lipase, cellulase and protease. Of the 46 bacteria isolated from humid areas, $41 \%$ presented lipolytic activity, $30 \%$ cellulolytic activity, 19\% amylolytic activity and $8 \%$ proteolytic activity (Bibi et al. 2017).

In view of current problems concerning bacterial resistance to multiple drugs, environmental bacteria have also been researched as sources of new substances with antimicrobial properties (Ventola 2015, Brown \& Wright 2016). The antimicrobial activity displayed by Bacillus sp. sed 2.2 was initially observed in the exponential growth phase, reaching maximum activity of $100 \mathrm{AU} / \mathrm{ml}$ from the beginning to the end of the stationary phase (between 33 and 48h). Liu et al. (2015) observed that antimicrobial activity was greatest between 36 and $60 \mathrm{~h}$ with $320 \mathrm{AU} / \mathrm{ml}$. Embaby et al. (2014) found that the beginning of the production of the antimicrobial substance was registered in the exponential phase, followed by an increase during the stationary phase of growth, reaching its maximum peak at 62 h of cultivation. These data demonstrate that these produced substances have secondary metabolite kinetics.
The antimicrobial substance studied was partially purified with a combination of ammonium sulfate precipitation and gel filtration liquid chromatography. Results showed that antimicrobial activity was precipitated by an ammonium sulfate, which matches results published for other antimicrobial substances from Bacillus spp. (Alanazi et al. 2016, Lim et al. 2016). The results of the gel filtration chromatography also point to the fact that the substance produced by Bacillus sp. sed 2.2, which eluted in the void volume of the Sephadex G-100 column, may have been forming aggregates of high molecular weight (> $150 \mathrm{kDa}$ ). Shi et al. (2015) used ammonium sulfate precipitation and dialysis to partially purify an antimicrobial substance from B. subtilis that exhibited a broad spectrum of action, including S. aureus, E. coli and some environmental pathogens. In a similar manner, Boottanun et al. (2017) worked with a partially purified substance. The protocols adopted were the same as those mentioned above, after which the antimicrobial activity was evaluated using the Burkholderia pseudomallei strain and other pathogenic bacteria. In our research, the antimicrobial substance was tested using Gram-positive, Gram-negative

Table IV. Antimicrobial spectrum of crude supernatant from Bacillus sp. sed 2.2.

\begin{tabular}{|c|c|c|}
\hline Indicator cultures & Incubation temperature (oC) & Halo (mm) - Average \\
\hline Corynebacterium fimi NCTC 7547 & 37 & 5 \\
\hline Listeria monocytogenes ATCC 7644 & 30 & 9 \\
\hline Listeria seeligeri BQ Oxford - 1 (counter top surface) & 30 & 9 \\
\hline Listeria seeligeri BP Palcam - 2 (counter top surface) & 30 & 9 \\
\hline Listeria seeligeri PF Oxford - 3 (sliced ham) & 30 & 7 \\
\hline Listeria seeligeri MP Oxford - 4 (hands) & 30 & 9 \\
\hline Listeria seeligeri BP Oxford - 5 (counter top surface) & 30 & 9 \\
\hline
\end{tabular}


and yeast bacteria. The substance isolated in this work inhibited the growth of C. fimi NCTC 7547 and some Listeria strains, including L. monocytogenes ATCC 7644. However, the substance was not able to inhibit Gram-negative bacteria or yeasts, therefore demonstrating a more restricted spectrum of action. Lee \& Chang (2018) tested a new bacteriocin from B. subtilis against Gram-positive and Gram-negative bacteria and observed inhibition of Grampositive bacteria such as Bacillus cereus and $L$. monocytogenes.

In this research, some physicochemical properties of the antimicrobial substance produced by the isolated Bacillus sp. sed 2.2 were studied, such as thermal stability and stability against proteolytic enzymes. There was no thermal inactivation at 100 oC for 3, 5 and 10 minutes. Chalasani et al. (2015) worked with a substance produced by Bacillus sp. which was stable at different temperatures, maintaining $80 \%$ of its activity at 80 oc for 1 hour, $75 \%$ of its activity at 100 으 for 30 minutes. Jemil et al. (2017) evaluated the thermostability of a lipopeptide produced by Bacillus methylotrophicus, this substance was resistant to heating for 20 minutes at temperatures up to $100^{\circ} \mathrm{C}$.

The antimicrobial activity of the studied substance was sensitive to the tested proteases (papain and trypsin), indicating that the compound is of a protein nature. The trypsin cleavage site is highly specific, cleaving the peptide bond after residues with long side chains of positive charge, arginine and lysine (Berg et al. 2014). Bacteriocins that are not sensitive to trypsin, probably do not have a lytic site for this protease. Some bacteriocins produced by Bacillus sp. are sensitive to trypsin and papain, such as: trypsin-sensitive N2-4 (Boottanun et al. 2017), trypsin-sensitive RX 7 (Lim et al. 2016). There are also compounds that are partially sensitive to proteases, such as the bacteriocin produced by Bacillus cereus BLIS m6c and BLIS m387 (Minnaard \& Alippi 2016) N3-8 (Boottanun et al. 2017). Sharma et al. (2018) purified and characterized a bacteriocin produced by Bacillus subtilis GAS 101, according to the authors, bacteriocin did not show antimicrobial activity against $S$. epidermidis after treatment with trypsin, pepsin and proteinase $\mathrm{K}$.

In conclusion, the isolates obtained from sediment samples yielded important sources of bioactive compounds, including substances with antimicrobial and enzymatic potential. Studying these properties and the applicability of these compounds opens up an important window of research, both with regard to prospecting new molecules presenting biological activity of interest, as well as to understanding the functionality of isolates from sampled environments.

\section{Acknowledgments}

This work received financial support from Coordenação de Aperfeiçoamento de Pessoal de Nivel Superior (CAPES, Brazil) and Universidade Federal do Rio Grande do Sul (UFRGS, Brazil).

\section{REFERENCES}

ALANAZI AS, QURESHI KA, ELHASSAN GO \& ANDEL-AGAMY EI. 2016. Isolation, purification and characterization of antimicrobial agent antagonistic to Escherichia coli ATCC 10536 produced by Bacillus pumilus SAFR-032 isolated from the soil of Unaizah, Al Qassim Province of Saudi Arabia. Pakistan J Biol Sci 19(5): 191-201.

ANSOLA G, ARROYO P \& MIERA LES. 2014. Characterisation of the soil bacterial community structure and composition of natural and constructed wetlands. Sci Total Environ 473-474: 63-71.

ARROYO P, SAENZ DE MIERA LE \& ANSOLA G. 2015. Influence of environmental variables on the structure and composition of soil bacterial communities in natural and constructed wetlands. Sci Total Environ 506: 380-390.

ARUMUGAM T, KUMAR PS, KAMESHWAR R \& PRAPANCHANA K. 2017. Screening of novel actinobacteria and characterization of the potential isolates from mangrove 
sediment of south coastal India. Microb Pathogen 107: 225-233.

BERG JM, TYMOCZKI JL \& STRYER L. 2014. Bioquímica. 7a. ed. Rio de Janeiro: Guanabara Kogan, 1912 p.

BIBI F, ULLAH I, ALVI SA, BAKHSH SA, YASIR M, AL-GHAMDI AAK \& AZHAR EI. 2017. Isolation, diversity, and biotechnological potential of rhizo and endophytic bacteria associated with mangrove plants from Saudi Arabia. Genet Mol Res 16(2): doi:10.4238/gmr16029657.

BOOTTANUN P, POTISAP C, HURDLE JG \& SERMSWAN RW. 2017. Secondary metabolites from Bacillus amyloliquefaciens isolated from soil can kill Burkholderia pseudomallei. AMB Express 7: 16. http://doi.org/10.1186/ s13568-016-0302-0.

BROWN ED \& WRIGHT GD. 2016. Antibacterial drug discovery in the resistance era. Nature 529: 336-343.

CHALASANI AG, DHANARAJAN G, NEMA S, SEN R \& ROY U. 2015. An Antimicrobial Metabolites from Bacillus sp.: Significant Activity Against Pathogenic Bacteria Including Multidrug-Resistant Clinical Strains. Front Microbiol 6: 1335. doi:10.3389/fmicb.2015.01335.

CORREIA JLA, DOS SANTOS TR, DA SILVA AA \& MARQUES OM. 2014. Isolamento, identificação e avaliação do potencial enzimático de bactérias autóctones de sedimento de mangue da Lagoa do Araça - PE. 2014. Disponível em: < http://pdf.blucher.com.br.s3-sa-east1. amazonaws.com/chemicalengineeringproceedings / cobeq2014/1127-20849-180947.pdf> Acesso em 15 jun. 2018.

DING X, PENG X-J, JIN B-S, XIAO M, CHEN J-K, LI B, FANG C-M \& NIE M. 2015. Spatial distribution of bacterial communities driven by multiple environmental factors in a beach wetland of the largest freshwater lake in China. Front Microbiol 6: 129.

DUARTE AFDS, CEOTTO H, COELHO MLV, BRITO MAVDP \& BASTOS MDCDF. 2013. Identification of new staphylococcins with potential application as food biopreservatives. Food Control 32: 313-321.

EMBABY AM, HESHMAT Y, HUSSEIN A \& ANDMAREY HS. 2014. A sequential statistical approach towards an optimized production of a broad spectrum bacteriocina substance from a soil bacterium Bacillus sp. YAS 1 strain. Sci World J 2014: 396304.

FRAZIER WC \& RUPP P. 1928.Studies on the proteolytic bacteria of milk: a medium for the direct isolation of caseolytic milk bacteria. J Bacteriol 16: 57-63.

GHANI M, ANSARI A, AMAN A, ZOHRA RRA, SIDDIQUI NN \& UL QADER SA. 2013. Isolation and characterization of different strains of Bacillus licheniformis for the production of commercially significant enzymes. Pakistan J PharmSci 26: 691-697.

GONTANG EA, FENICAL W \& JeNSEN PR. 2007. Phylogenetic diversity of gram-positive bacteria cultured from marine sediments. Appl Environ Microbiol 73: 3272-3282.

HANKIN L \& ANAGNOSTAKIS SL. 1975. The use of solid media for detection of enzyme production by fungi. Mycologia 67: 597-607.

HAUSDORF L, MUNDT K, WINZER M, CORDES C, FRÖHLING A, SCHLÜTER O \& KLOCKE M. 2013. Characterization of the cultivable microbial community in a spinach processing plant using MALDI-TOF MS. Food Microbiol 34(2): 406-411.

HU BI ET AL. 2014. Evidence for nitrite-dependent anaerobic methane oxidation as a previously overlooked microbial methane sink in wetlands. Proc Natl Acad Sci USA 111(12): 4495-4500.

JEMIL N, AYED HB, MANRESA A, NASRI M \& HMIDET N. 2017. Antioxidant properties, antimicrobial and antiadhesive activities of DCS1 lipopeptides from Bacillus methylotrophicus DCS1. BMC Microbiology. 17: 144. doi:10.1186/s12866-017-1050-2.

JUNGBLUT AD, WOOD SA, HAWES I, WEBSTER-BROWN J \& ANDHARRIS C. 2012. The pyramid trough wetland: environmental and biological diversity in a newly created Antarctic protected area. FEMS Microbiol Ecol 82(2): 356-366.

JUNK WJ. 2013. Current state of knowledge regarding South America wetlands and their future under global climate change. Aquatic Sci 75: 113-131.

KÉKESSY DA \& PIGUET JD. 1970. New Method for Detecting Bacteriocin Production. Appl Microbiol 20(2): 282-283.

KOPCAKOVA A, STRAMOVA Z, KVASNOVA S, GODANY A, PERHACOVA Z \& PRISTAS P. 2014. Need for database extension for reliable identification of bacteria from extreme environments using MALDI TOF mass spectrometry. Chem Papers 68(11): 1435-1442.

KUMAR PS, DURAIPANDIYAN V \& ANDIGNACIMUTHU S. 2014. Isolation, screening and partial purification of antimicrobial antibiotics from soil Streptomyces sp. SCA 7. Kaohsiung J Med Sci 30: 435-446.

LEE SG \& CHANG HC. 2018. Purification and characterization of mejucin, a new bacteriocin produced by Bacillus subtilis SN7. LWT Food SciTechnol 87: 8-15.

LEITE AJ, TULINI LF, TEIXEIRA BR, RABINOVITCH L, QUINTANILHA JC, GONSALES RN, CABRAL H \& DE MARTINS CP. 2016. Bacteriocin-like inhibitory substances (BLIS) produced 
by Bacillus cereus: Preliminary characterization and application of partially purified extract containing BLIS for inhibiting Listeria monocytogenes in pineapple pulp. Food SciTechnol 72: 261-266.

LI Y, WU C, ZHOU M, WANG ET, ZHANG Z, LIU W, NING J \& XIE Z. 2017. Diversity of cultivable protease-producing bacteria in Laizhou Bay sediments, Bohai Sea, China. Front Microbiol 8: 405. doi: 10.3389 / fmicb.2017.00405.

LIGI T, OOPKAUP K, TRUUA M, PREEMA JK, NÕLVAKA H, MITSCHWJ, MANDER Ü \& TRUUA J. 2014. Characterization of bacterial communities in soil and sediment of a created riverine wetland complex using high-through put 16S rRNA amplicon sequencing. Ecol Eng 72: 56-66.

LIM KB, BALOLONG MP, KIM SH, OH JK, LEE JY \& KANG DK. 2016. Isolation and characterization of a broad spectrum bacteriocin from Bacillus amyloliquefaciens RX7. BioMed Res Int Article ID 8521476.http://dx.doi. $\operatorname{org} / 10.1155 / 2016 / 8521476$.

LIU X, LEE JY, JEONG SJ, CHO KM, KIM GM, SHIN JH, KIM JS \& ANDKIM JH. 2015. Properties of a bacteriocina produced by Bacillus subtilis EMD4 isolated from Ganjang (soy sauce). J Microbiol Biotechnol 25(9): 1493-1501.

LOVECKA P, PACOVSKA I, STURSA P, VRCHOTOVA B, KOCHANKOVA L \& ANDDEMNEROVA K. 2015. Organochlorinated pesticide degrading microorganisms isolated from contaminated soil. New Biotechnol 32(1): 26-31.

MARRA A, DIB-HAJJ F, LAMB L, KACZMAREK F, SHANG W, BECKIUS G, MILICI AJ, MEDINA I \& GOOTZ TD. 2007. Enterococcal virulence determinants may be involved in resistance to clinical therapy. Diagn Microbiol Infect Dis 58-54: 59-65.

MINNAARD J \& ALIPPI AM. 2016. Partial characterization of bacteriocin like compounds from two strains of Bacillus cereus with biological activity against Paenibacillus larvae, the causal agent of American Foulbrood disease. Lett Appl Microbiol 63(6): 442-449.

MOHKAM M, NEZAFATN, BERENJIAN A, MOBASHER MA \& GHASEMIY. 2016. Identification of Bacillus probiotics isolated from soil rhizosphere using 16S rRNA, recA, rpoB gene sequencing and RAPD-PCR. Probiotics Antimicrob Prot 8: 8-18.

MONTANHINI MTM \& BERSOT LS. 2013. Evaluation of psychrotrophic behavior and lipolytic and proteolytic activity of Bacillus cereus isolated from refrigerated dairy products. Acta Scientiarum Technol 35(1): 163-167.

MORA I, CABREFIGA J \& MONTESINOS E. 2015. Cyclic lipopeptídeo biosynthetic genes and products, and inhibitory activity of plant-associated Bacillus against phytopathogenic bacteria. PLoS ONE 10(5): e0127738.

MOTTA AS \& BRANDELLI A. 2002. Characterization of an antibacterial peptide produced by Brevibacterium linens. J Appl Microbiol 92: 63-71.

MOTTA AS, CANNAVAN FS, TSAI S-M \& BRANDELLI A. 2007. Characterization of a broad range antibacterial substance from a new Bacillus species isolated from Amazon basin. Arch Microbiol 188: 367-375.

PANOSYAN H, HAKOBYAN A, BIRKELAND NK \& TRCHOUNIAN A. 2018. Bacilli community of saline-alkaline soils from the Ararat Plain (Armenia) assessed by molecular and culture-based methods. Syst Appl Microbiol 41: 232-240.

RAMAPRIYAR,THIRUMURUGANA,SATHISHKUMART\&MANIMARAN DR. 2018. Partial purification and characterization of exoinulinase produced from Bacillus sp. J Genet Eng Biotechnol 16(2): 363-367.

RICHARDSON SJ, CLAYTON R, RANCE BD, BROADBENT $H$, MCGLONE MS \& WILMSHURST JM. 2015. Small wetlands are critical for safeguarding rare and threatened plant species. Appl Vegetation Sci 18: 230-241.

SALAZAR F, ORTIZ A \& SANSINENEA E. 2017. Characterisation of two novel bacteriocin-like substances produced by Bacillus amyloliquefaciens ELI149 with broadspectrum antimicrobial activity. J Global Antimicrob Resist 11: 177-182.

SANSINENEA E, SALAZAR F, JIMÉNEZ J, MENDOZA Á \& ORTIZ A. 2016. Diketopiperazines derivatives isolated from Bacillus thuringiensis and Bacillus endophyticus, establishment of their configuration by X-ray and their synthesis. Tetrahedr Lett 57: 2604-2607.

SAUGET M, VALOT B, BERTRAND X \& HOCQUET D. 2017. Can Maldi-tof mass spectrometry reasonably type bacteria? Trends Microbiol 25(6): 447-455.

SHARMA G, DANG S, GUPTA S \& GABRANI R. 2018. Antibacterial Activity, Cytotoxicity, and the Mechanism of Action of Bacteriocin from Bacillus subtilis GAS101. Med Princ Pract 27(2): 186-192. doi: 10.1159/000487306.

SHASHIDAR A, MARC O, DELPHINE D, EDWIN DE P, KUNLING C, SAROSH B \& JOHAN M. 2017. Insights into the molecular basis of biocontrol of Brassica pathogens by Bacillus amyloliquefaciens UCMB5113 lipopeptides. Ann Botany 120(4): 551-562.

SHI B, ZHENG H, HUANG J, LUOX \& LUO X. 2015. Purification and partial characterization of a thermostable antimicrobial protein from Bacillus subtilis FB123. World J Microbiol Biotechnol 31: 1285-1290. 
STAROSTIN KV, DEMIDOV EA, BRYANSKAYA AV, EFIMOVVM, ROZANOV AS \& PELTEK SE. 2015. Identification of Bacillus strains by MALDI TOF MS using geometric approach. Sci Rep 5: 16989.

TEDESCO MJ, GIANELLO C, BISSANI CA, BOHNEN H \& VOLKWEISS SJ. 1995. Análise do Solo, Plantas e Outros Materiais. 2 ed., rev. e ampl. Porto Alegre: Departamento de Solos, UFRGS, $174 \mathrm{p}$.

TIMPERIO AM, GORRASI S, ZOLLA L \& FENICE M. 2017. Evaluation of MALDI-TOF mass spectrometry and MALDI BioTyper in comparison to 16S rDNA sequencing for the identification of bacteria isolated from Arctic sea water. PLOS ONE 12(7): e0181860.

VENTOLA CL. 2015. The antibiotic resistance crisis: Part 1: causes and threats. Pharm Therapeut 40(4): 277-278.

\section{How to cite}

JANKOSKI PR, CORREA APF, BRANDELLI A \& DA MOTTA AS. 2021. Biological activity of bacteria isolated from wetland sediments collected from a conservation unit in the southern region of Brazil. An Acad Bras Cien 93: e20191269. DOI 10.1590/0001-3765202120191269.

Manuscript received on October 17, 2019;

accepted for publication on February 23, 2020

\section{PRISCILA R. JANKOSKI ${ }^{1}$}

https://orcid.org/0000-0003-1204-9939

\section{ANA PAULA F. CORREA ${ }^{2}$}

https://orcid.org/0000-0001-7588-5657

\section{ADRIANO BRANDELLI ${ }^{2}$}

https://orcid.org/0000-0002-9307-6471

\section{AMANDA S. DA MOTTA}

https://orcid.org/0000-0001-8637-3868

'Universidade Federal do Rio Grande do Sul, Instituto de Ciências Básicas da Saúde, Departamento de Microbiologia, Imunologia e Parasitologia, Rua Sarmento Leite, 500, sala 216, Cidade Baixa, 90050-170 Porto Alegre, RS, Brazil

${ }^{2}$ Universidade Federal do Rio Grande do Sul, Instituto de Ciência e Tecnologia de Alimentos, Departamento de Ciência dos Alimentos, Av. Bento Gonçalves, 9500, Campus do Vale, Prédio 43212, Santo Antônio, 91501-970 Porto Alegre, RS, Brazil

Correspondence to: Amanda de Souza da Motta

E-mail:amanda.motta@ufrgs.br

\section{Author contributions}

Priscila Ribeiro Jankoski: Conducted the collection of sediment samples, performed the analyzes and wrote the manuscript. Ana Paula Folmer Correa: Assisted in chromatographic analysis. Adriano Brandelli: Revised the manuscript. Amanda de Souza da Motta: conceived the idea; assistance in purification analysis and manuscript review. All authors read and approved the manuscript.

\section{(cc) BY}

